\title{
AFRICAN VOICES AND ACTIVISTS AT THE WSF IN NAIROBI: THE UNCERTAIN WAYS OF TRANSNATIONAL AFRICAN ACTIVISM
}

\author{
Marie-Emmanuelle Pommerolle \\ Lecturer in Politics \\ University Antilles-Guyane, Campus Jacob \\ mepommerolle@free.fr \\ Johanna Siméant \\ Professeure de science politique \\ I'Université Paris 1 \\ jsimeant@univ-paris1.fr
}

\begin{abstract}
Transnational social movement studies have long neglected the way activists from the South, and particularly from Africa, have participated in World Social Forum processes. Alterglobal activists have also been accused of neglecting or dominating southern voices. The organization of the WSF in Nairobi was seen as an opportunity to make African voices be heard. This examines how Africans activists participated in Nairobi, and the complex relationship they have to northern and other southern (such as Asia and Latin America) activists. The African alterglobal movement is seen as a space of tensions (i.e. between South Africans and the rest of the continent, between French and English speaking Africa, or between NGOs and more radical organizations) reflected in national mobilizations. Our team of 23 French and 12 Kenyan scholars made collective ethnographic observations in more than a hundred workshops and conducted 150 biographical interviews of African activists in order to examine how: Africa was referred to in the WSF; activists financed their trip to Nairobi; and Afrocentric, anti-imperialist, and anticolonial arguments have been used.
\end{abstract}

\section{INTRODUCTION}

Although a rich literature has developed on World Social Forums (WSF), regional Social Forums, and other transnational contentious gatherings, and scholars have carried on surveys on their composition and participation (Agrikoliansky and Sommier 2005; della Porta and Tarrow 2005), few studies have addressed what is at stake with the localization, both geographic and symbolic, of the Forums. Why observe the WSF in particular? First of all, even if the other WSFs also took place in the "Global South", the 2007 WSF was the first one held in Africa, if one excludes the polycentric social forum of January 2006, held in Bamako, Karachi, and Caracas. The organizers of this forum were not unaware of the stakes in making African voices heard and incarnating Africa, the more so as Africa is perceived as the continent most victimized by globalization. 


\section{JOURNAL OF WORLD-SYSTEMS RESEARCH}

Reflecting on Africa at the WSF in Nairobi means at the same time thinking about the emergence of an African alterglobalism, incarnated inter alia by the African Social Forum (ASF). ${ }^{1}$ It also implies reflections on the diversity of transnationalized African networks (both in organizational and ideological terms), on the tensions between the latter, and on the complex relationship these networks have to northern, and other southern (such as Asia and Latin America) activists. The African alterglobal movement, if anything, is a field of multiple tensions.

To observe the World Social Forum in Nairobi from the point of view of the South, in particular, Africa-and its participants, is thus a means of addressing some of the shortcomings of the sociology of transnational social movements, much of which remains today, despite some exceptions (Wood 2005; Rothman and Oliver 2002), mainly centered on Western civil societies, or, at best, on transnational campaigns concerning the South (dams, child work, debt), but mainly animated by northern activists. We know that transnational militancy of the South exists, but it is generally considered to be an adaptation or an appropriation of external dynamics (Bob 2002; Wing 2002). We are not satisfied with the binary explanations of this activism (seen either as an emergent sui generis civil society, or as the "compradors" of an ever-patronizing North). This is why we would like to show how African activists managed to participate in the WSF in Nairobi and what the conflicts were surrounding the right to talk about, for, and from, Africa. These questions are linked. In an alterglobal space which seeks to obscure them, it is important here to think about the hierarchies, the conflicts, or even quite simply, the division of labor within transnational activism. That presupposes attention to the social and material conditions of activism (Wagner 2004). Agency, identity, and injustice (Gamson 1992), the three central components of collective action, do not rest only on intentional and strategic use of symbols. More precisely, the manipulation of symbols is always deeply rooted in social settings. A robust materialism is often what allows us, by pointing to the constraints of collective action in a transnational setting marked by huge divides in terms of resources, to understand what is at stake in ideological constructions that denounce injustices or build bridges amongst African activists themselves, or between them and other transnational activists.

\section{METHODS AND DATA}

Our aim was to understand the links between material constraints, activists' socialization, interactions between the participants in the WSF, and the stake of African representation in the Forum, not only in terms of numbers, but also in the content of the debates. A wide scale qualitative methodology was seen to be most appropriate one. Our work, therefore, is based on a collective survey conducted in Nairobi in January, 2007. A team of 23 French and 14 Kenyan scholars $^{2}$ carried out collective ethnographic observations in 130 workshops of the WSF, along

\footnotetext{
${ }^{1}$ As in political action, words are an issue, we chose to use the term "alterglobal" (a translation of the French "altermondialiste") movement which is used by many European and Latin American activists, and which is preferred to the "Global Justice Movement," perceived as too consensual and too Anglo-Saxon.

${ }^{2}$. Apart from the authors, the following people were involved in the project: Evelyn Awino, Idris Irshad, Lilian Kayaro, Leonard Wambaya, Charles Mutua, Mwadzoya Mwandeje, John Ndung'u, Margaret Njeru, Nicholas Odoyo, Oita Etyang, Vincent Opondo, Andrew Otieno Aura, Lizz
} 
with 150 interviews with African activists at the forum. The ethnographic observation was aimed at observing the composition of the audience, the content, language, and rhetorical form of the debates, and the way in which Africa was referenced by speakers. A standardized observation sheet, combined with photos and sometimes recording or filming, was used as a support for the small ethnographic reports which included analytical elements summarized after the workshops or the observations. The interviews had a biographical section as well as one more focused on the practical aspects of the participation in the WSF, for example: was it the first trip abroad; how did activists manage to pay for their trip to Nairobi; did they belong to non-governmental organizations (NGOs) or other kinds of organizations?

In order to combine an analysis of the social conditions and the symbolic work of protest in this forum in Africa, this article is divided into two parts. The first part will answer the question: "whose forum was it?" and will focus on the material conditions of attendance at the WSF and how they were translated into debates about the representativeness of this Forum. The second part will answer the question "whose voices were heard?" during the forum focusing on the ways identities and legitimate claims to speak in the name of Africa were built in a space of tensions.

\section{WHOSE VOICES? SPEAKING IN THE NAME OF AFRICA: DOUBLE BINDS AND CENSORSHIP}

This World Social Forum, more than others, was an opportunity to observe how activists from Africa and the rest of the world speak about Africa in an internationalized activist gathering. This helps us to understand the difficulties faced by all movements that intend to denounce domination and at the same time display agency (Gamson 1992) as well as the constraints faced by internationalized actors who claim to authentically represent their constituencies. Because the current situation in Africa seemed to provide obvious proof of the misdeeds of globalization and capitalism, mobilizing in turn in the name of Africa did not go without constraints or even double binds.

\section{Agency and Domination}

This is the classical double bind of social movements to, on the one hand, be able to criticize situations of misery without falling into pessimism or impotence, and on the other, to celebrate agency without falling into populism, thus ignoring real difficulties or dismissing possible supporters or allies by a supercilious claim of cultural and political autonomy. These are the traditional and intersecting dilemmas of pessimism and populism (Grignon and Passeron 1989). In Nairobi, Africa was, at the same time, acted upon and the actor; in practice and in words.

Kariuki, Benjamin Osiemo, Dominique Connan, Mathilde Debain, Nedjib Sidi Moussa, Fanny Laredo, Fernando Isern, Marie Baget, Camille Le Coq, Julie Aubriot, Marame Ndour, Guillaume Thiery, Xavier Audrain, Samadia Sadouni, Thomas Atenga, Nathanaël Tstotsa, Alphonse Maindo, Florence Brisset, Sara Dezalay, Pascal Dauvin, Lilian Mathieu, Dominique Cardon, Nicolas Haeringer, Ayito Nguema. All conducted interviews and/or ethnographic observations and should be therefore thanked. 


\section{JOURNAL OF WORLD-SYSTEMS RESEARCH}

These constraints weighed both on African and non-African activists, the latter always trying to preempt possible charges of paternalism as they expressed various degrees of ethnocentrism in their relations with African causes and activists.

Was this WSF a success or not? The answers to this question, during and after the forum, revealed the position of non-African activists towards Africa (as a reality that they knew more or less, and as an issue that mattered more or less). The members of the African social Forum, and the representatives of the Kenyan Organization Committee, claimed that the criticisms of the organization focused on elements that should have been excusable or ignored the difficulties specific to Africa, and revealed the "neocolonialism" of some northern activists. Many representatives of INGOs, more familiar with Africa than some of their radical counterparts, found, sometimes not without paternalism, that "for Africa", this WSF was a success. Conversely, the most virulent critics of the organization were often those for which the African dimension of the forum was not an issue. Some, such as the networks of the CADTM, wished to denounce "the elite" of the ASF. Others argued that since a country of the South had succeeded in organizing a WSF with much popular local participation (as in Mumbai) there was no point in sparing the feelings of Kenyan organizers.

Northern activists often feared being seen as patronizing. Thus at the WSF, they seldom criticized African governments, even the most repressive. Supporting anti-imperialism and defending activists everywhere can be touchy. At most NGOs considered some African governments as "puppets" or accomplices of northern governments. They, therefore, let Africans decide whether to criticize their leaders or not. Thus, in a workshop on "Extractive and local livelihoods", activists of the Niger Delta accused the federal government of Nigeria of being an accomplice of the oil companies, while the Western participants denounced "an ugly face of capitalist exploitation and blamed it on the US and Britain." Admittedly, there is nothing more widely shared than anti-imperialism at a WSF, especially since this term has seen a revival, for instance through the writings of Negri and Hardt. But even Northern activists' solicitude towards the "victims of imperialism" could be perceived as patronizing. That explains the uncomfortable position of northern activists in a number of workshops. When the debates corresponded to what they claimed to desire (a speech of the South on the South), they tended to offer their help by encouraging civil societies from the North to criticize governments of the North, and let civil society actors from the South, if they wished or could, to criticize their own governments. They thus set out a form of international division of labor for criticism of governments. For example, in a workshop on AIDS, a Canadian woman speaking to a mainly African audience claimed, "One is complementary. We must put pressure on our governments, and you on yours so that they do not pay the debt that you do not pay for colonialism. Mobilize yourself to let us know your goals" (Fieldwork notes, January $24^{\text {th }}$, 2007).

Northern activists, of course, do not have a unified perception of Africa, as very diverse militant layers coexist within the WSF including: development and aid organizations; Trotskyites opposed to war; Christian militants against the debt; mainstream or radical feminists; and "first hour anti-colonialists”, who have struggled since the 1950s, against the domination of the North. Moreover, the behavior of northern activists and their ethnocentrism sometimes had less to do with their ideologies, and more to do with their familiarity with the African continent, their socialization or their social position. Such radical activists vilified the venality of the African "volunteers" of the WSF (most of whom were, in fact, paid). Some participants took photos of street children without questioning the meaning of their actions. Other radical militants would 
insist on putting their local partners (whose travel their organization had financed) out in forefront as evidence of the grassroots constituencies in their NGO. Radical "tiers-mondistes" 3 would stay in one of the very comfortable hotels necessary to host the whole delegation and its meetings and to ensure access to the Internet. Conversely, those most familiar with the continent did not idealize the participation of the poorest Kenyans, and did not regard the looting of an overly expensive food concession (owned by a close relative of the Kenyan Minister of Home Affairs) by street children as a completely positive act, instead worrying about what might become of these children once the activists who had supported them had departed.

A striking aspect of WSFs in general, and this one in particular, is the reactivation of an ideology shaped around the third-world, which had been strongly challenged in the 1980s. Its strong presence is undoubtedly linked to the convergences it permits, sometimes due to its vagueness. In various workshops in Nairobi, one could re-discover dependency theory (Samir Amin, its most renowned African theorist, was among the "stars" of the WSF) and "Third Worldism." "The Third world is the third estate of the world", declared Gus Massiah, of the Centre d'Etudes Anti Impérialistes (CEDETIM) having rediscovered the origin of the term Third World. Liberation theology (with one of its main theorists, the sociologist François Houtard), all forms of anticolonialism (the "Franz Fanon space" was particularly active) and finally Afrocentrism, either in its Afro-American (Malcom X grassroots movement), or African versions (seen in many references to Sheik Anta Diop) were all represented in the program. Throughout the WSF, a moderated form of Afrocentrism thus seemed to be one of the processes making it possible to claim agency and to mobilize identity and pride, while denouncing the fate imposed on Africa. Thus Afrocentrism was a way of binding what Gamson (1992) identified as the three central components of collective action: injustice, agency, and identity.

A first aspect of this Afrocentrism consisted of pointing out what Africa could be proud of, including celebrating great African intellectuals such as Sheik Anta Diop and Joseph Ki Zerbo. The great historical figures of African independence struggles were evoked through the names given to the physical spaces of the forum. Meeting places were given exclusively African names (except for Che Guevarra) such as Amilcar Cabral, Chris Hani, Dedan Kimathi, Mary Nyanjiru, Mekatilili Wa Menza, Modibo Keita, Patrice Lumumba, Ruth First or Thomas Sankara - all of whom were martyrs of colonialism or apartheid, or more precisely, the fight against apartheid. Many speeches at the opening ceremony were peppered with shouts of "Amandla."

The choice of names for meeting places speaks for itself; as it represents the ambivalent relationship African alterglobalists have to African leaders. On the one hand, they strongly assert the sovereignty of African states, but are aware that this can be used by governments as a tool for legitimation, as was done historically when anti-imperialism was fastened onto a project of national construction. On the other hand, they criticize the "puppets of the North" (i.e. their own national leaders). Direct criticism of the corruption of some African leaders is done more in private situations, between activist friends, from the North or the South, not only out of fear of reprisals once they have returned home. While "beginner" activists (here, Kenyans, peasants, squatters, hawkers who came to testify at the WSF) did not hesitate to clearly denounce their political leaders senior activists, in contrast, have adopted, since their beginnings, an ambivalent attitude toward leaders. The dilemma faced by the majority of critics of domination is what can

\footnotetext{
${ }^{3}$ Literally "third-worldist", refers to this powerful ideology born in the 1950s and which took its name in France in reference to the Third-Estate of the French Revolution.
} 


\section{JOURNAL OF WORLD-SYSTEMS RESEARCH}

be said against these leaders that will not be exploited by adversaries? This constraint arises within nationalist or anti-imperialist frameworks since criticizing African leaders can provide new arguments for international financial institutions like the IMF and the World Bank who are always eager to denounce corruption and encourage "good governance.” PanAfricanism, the call for a true United States of Africa, seems to have been a way of challenging African leaders without having to spell it out, because in calling for union there is an implicit critique of colonization and its inherited borders. The denunciation of debt is a very revealing example of these rhetorical strategies. The example of the debt of the Democratic Republic of Congo is often used undoubtedly because it makes it possible to criticize a former African leader, Mobutu and explain why Africans should not have to pay the debt of this illegitimate dictator who was supported by Western countries. It thus allows Africans to say that western countries are still responsible and should be accountable for the horrors committed by their ancestors.

More generally this form of "side" criticism, which consists of denouncing vague or remote culprits and processes (be they European Partnership Agreements, IFIs, the North, imperialism, or the heritage of colonization), was frequently heard in Nairobi. This form of criticism indeed makes it possible to endorse a critical discourse, even when one is a citizen of an authoritarian regime, by thus reconciling a moderate activism within one's national space, with a radical language directed towards external enemies in international circles-leaving the question of accountability of African national leaders blurred. This seems to be very characteristic of what the alterglobalist discourse allows. It is amplified by the fact that African activists seldom dare to confront their own leaders head on.

Another way of combining agency and the critique of domination was observed in speeches evoking the evils of Africa but, at the same time, denying these evils by claiming that Africa is so much more than that. Kenyan activist Wahu Kaara's speech at the opening ceremony of the WSF reflected this form of expression, which, in the context of an energetic speech, mobilized, indeed, a form of agency. "Welcome to Wahu Kaara, the African revolutionary!" says the presenter on stage. After a series of "Karibu" and "Welcome", she explains to her audience why Nairobi is welcoming:

"Africa is not a dying continent!"

"Africa is not a (bargain) continent!"

"Africa is not a poor continent!"

"Africa is not a dying continent!"

"Africa is not a continent of diseases!"

"Africa is not a continent of malnutrition!"

"Africa is a continent of human spirit!"

(....) It can be very sentimental and very emotional... very sentimental and very emotional because we are here in Nairobi to say that Africa is here and now to stay!" (Yeah!) And I am saying this as an African woman because we have refused to die, we are living for Africa..." (fieldwork notes, 20th of January, Uhuru Park, Nairobi)

The making of this African agency also resulted in the delimitation of "them" and "us", as a way of tracing the borders between friends and enemies, between those who can legitimately 
claim to endorse the cause of Africa and those who cannot. Kaara's speech marked this very strong division between "us" and "them":

No matter what agendas THEY have... no matter what power THEY have... be it economic or be it political be it whatever... this time around the World Social Forum has given an opportunity to make a linkage with the others all other the world. (fieldwork notes, 20th of January, Uhuru Park, Nairobi)

This division among you/us/them appeared in many workshops. "Us" was used to represent Africa and "You" "the North." That could appear paradoxical in a forum defined, according to its charter, as an "open space", a coordination of civil society movements from all over the world. To point out this cleavage is a way to prevent northern activists from dominating struggles for the South. ${ }^{4}$ This you/us divide could be very situational, expressing the bitterness African activists felt when they realized that their accommodations or housing was far less comfortable than that of the Western activists, that many Africans did not have the financial means to buy the food or drink sold at the WSF venue at prices designed for Westerners, or when, in a workshop, people whom they felt had no legitimacy to talk monopolized speeches. Contesting this situation could very quickly make Westerners turn silent.

African identity within the WSF was thus prone to transformations depending on the interaction or situation. From the remote "Them" of the IFIs, that was central to building the inclusive "us" of the participants of the WSF, activists shifted quickly to a less clear "You" and "Us", that could crystallize a "situational anti-imperialism" where the "You" indicated the North, the whites, the moderate ones, that is, all those who were resigned too easily to the unjust order of the world. Conversely, a northern activist who idealized "African tradition" could be challenged for this caricatured and anti-modern vision of Africa. In before a mixed audience the reference to traditions "that work" is a classic one, and relates to the influence of certain currents of development ideology. The same could be observed when it came to religion, which could, according to the situation, be alternatively denounced, or on the contrary, placed at the very heart of the "African soul." The South African case is characteristic of this unstable African identity. South Africans enjoy or claim a strong legitimacy among Africans due to their fight against apartheid, but they are often regarded as insufficiently or "not exactly" African, as "a-typical" of Africa. These aspects thus raise questions about the forms of legitimacy claimed by these militants.

\section{Cultural Legitimism and Self-Censorships}

Organizing the World Social Forum in Africa was almost an injunction to make Africa central within the Forum. However this "injunction of Africa”, even as it opened a space of competition to speak in the name of Africa, resulted in various forms of claims of cultural legitimacy and authenticity, which also have to be understood in terms of class. What was at stake was the right to talk, sometimes against the North, but also vis-a-vis other African activists. The first aspect of

\footnotetext{
${ }^{4}$ The cleavage is then more North/South than Africa/North. During a Jubilee workshop, this young anti-debt activist from Norway was contradicted by an Ecuadorian activist who challenged "this guy from the North, a young man" (January, 24 ${ }^{\text {th }}$, 2007).
} 


\section{JOURNAL OF WORLD-SYSTEMS RESEARCH}

this cultural legitimism is asserting and representing traditions or cultural features and claiming that agency and identity result from one's own cultural resources. This probably is a classical phenomenon (Hobsbawm and Ranger 1983). This tradition could be a militant one, for example, the reference to independence and the struggle against Apartheid. Tradition was also asserted through forms of expression, such as singing or dancing, often done between the sessions, or at the beginning of them. But it could also be more largely depicted as an "African culture", sometimes idealized, often poorly defined in terms of consensus, a sense of community, the role of the family, the importance of elders and other traditional social bonds, or male/female complementarities.

But this reference to a (re)invented tradition did not have as its only role the dismissal of Northern activists perceived as too quick to take over struggles. Indeed, no militant from the North, within the WSF, dared to challenge an African activist as not having a legitimate right to speak. An African at the WSF was at least supposed to be a witness, even a victim, attesting personally to the misfortunes of Africa. Thus, in a workshop on migration, women who had tried to cross the desert told their stories and were listened to as victims. In a workshop at the Franz Fanon space a Kenyan from the Sengwer group explained how his community had been deprived of its land. This implicit assignment of Africans to the status of witness is ambivalent. It makes the people worth being heard, as much as is any activist. But in the WSF it turned every African talking into a potential witness, even when African activists did not endorse the nature of the testimony.

The issue of Africaness also had a central role in situations where the public was mainly African, and where one then saw competing strategies of representativeness. What seemed to be at stake in this internationalized space which sometimes looked much like any another international conference ${ }^{5}$, was to avoid being challenged as non-African (that is, being too "westernized", cut off from grassroots, traveling too much). This was the case for some Kenyan artists who performed at the Forum "in the name of a sacrifice for Africa", and who reluctantly acknowledged that they "lived" in the USA since they spent most of their time there for professional reasons. This example illustrates the tendency to a real cultural legitimism with a strong denial of extraversion (Bayart 2000) and internationalization. It raises a central issue, as charges of "not representing anybody" were often heard, in criticism of some "stars" of African alterglobalism. One cannot deny that the transnationalization of activism can contribute to widening the gap between the most internationalized activists, sometimes those most gifted with social and financial resources, and the others. Hence this insistence on showing that one is actually African, that is, "culturally" African, that one does not reproduce colonial patterns, does not travel, and is, therefore, more "rooted" than "cosmopolitan" (Tarrow 2005).

This insistence by all activists, either from the North or the South, in the denigration of extraversion and internationalization was particularly evident in the workshops relating to sexuality. Northern activists here tried to be particularly discrete, and avoid appearing to be imposing codes that would have been rejected if they had been promoted by the North. This was reflected in the following discussion of the Kasarani, Queer Spot, workshop "Reclaiming our sexualities" which took place on January $22^{\text {nd }}$, 2007. This workshop benefited from the organizational support of the International Lesbian and Gay Association (ILGA), reflected in the discrete presence of its communication Officer Stephen Barris, who confines himself to the

\footnotetext{
${ }^{5}$ On the specific culture of international spaces, see Riles (2001)
} 
Spanish/English translation. The goal was clearly to minimize the presence of whites on this theme during the entire forum, as Barris acknowledged in a report written after the WSF. ${ }^{6}$ This was by far the workshop where our team members heard the most discussion about what is "really" African, or Africa-like, in terms of references (the term "Mother Africa" was even used). The reproach that homosexuality is "not-African" appears to be the major obstacle to be addressed. The audience was mixed, with a small African majority. The large number of speakers provided limited opportunity for the audience to express themselves. With the speakers' short interventions, one after the other, the goal seemed to be increased visibility rather than a potentially explosive dialogue (although in small group dialogues with Kenyans in English and Kiswahili had been organized before). Four of the five speakers were African, all of them from English-speaking Africa. Two were South African; one a Ugandan refugee in South Africa; and the fourth was a Nigerian woman. The South-African activist and poetess explained LGBT struggles and described the use of homophobia by postcolonial leaders who affirmed that homosexuality was "un-African." She explained, "we are here precisely to re-conquer our sexualities". The Nigerian woman recounted the work she had carried on about homosexuality in Nigeria:

There are people who are born Nigerians, who are living in Nigeria, who have never left the Country, but who have same sex relationships (some applause). In English you would say they are homosexuals, in the local language it was more difficult to find a language for the behavior because with the advent of colonialism and Christianity and the Jihad that took place (...) a local language censorship has taken place as they try to institutionalize the moral code that they have brought in.

She recalls that although the absence of the term "homosexual" in her language is used to argue that the reality did not exist, there are traditional terms to indicate this type of relationship that can be discovered by questioning older people. The leader of the Coalition of African Lesbians then held up a collection of life stories and testimonies of lesbians in English-speaking Africa by a group of anthropologists. She insisted on the importance of this compilation, and challenged the idea that homosexuality is un-African, and called for a re-appropriation of terminology "to tell our communities who we are without using colonial language" (Fieldwork notes).

6 "At the closing ceremony on Thursday afternoon (...) We decide to ask for a speech to be read but the program is already overloaded: someone takes our script, but cannot guarantee that it will be read. In the following minutes, our speech in the name of "the gays and lesbians of Africa" is announced but does not materialize. One hour, two hours, three hours... Kasha, a Ugandan activist, and I decide to go backstage to ask what's going on. (...). An hour and a half passes, and finally comes her moment to shine. I wait behind the scenes: a European - especially a white man - would discredit the attempt by trying to speak in the name of the gays and lesbians of Africa". "World Social Forum - Nairobi 2007 Respect for All! Another world is possible - for African LGBT people, too", 26/02/2007, retrieved on Friday, 06 ${ }^{\text {th }}$ July 2007 (http://www.babels.org/forum/viewtopic.php?p=2961). 


\section{JOURNAL OF WORLD-SYSTEMS RESEARCH}

The same manner of speaking about what is really African and what is not could also be found in less radical workshops, connected to the world of international development and Northern INGOs, as for example, in workshops on AIDS and the best ways to fight HIV in Africa. This claim of Africaness here shouldn't, therefore, be understood as the result of a hypothetical and rigid "African culture", but rather as an illustration of the constraints faced by activists when trying to build a collective identity (Poletta \& Jasper 2001), and particularly an identity that couldn't be claimed by rival associates in the alterglobal movement. Transnationalisation of activism does not dilute national and cultural identities; rather, it encourages the assertion of identities that can be legitimately claimed as proof of having constituencies.

\section{CONCLUSION}

Examining African participation in the WSF suggests two important aspects that need to be taken into account in the study of transnational activism. The first is the necessity to examine concrete conditions, and the second is the fact that social movements cannot be considered unified actors. On the contrary, they should be seen as spaces of struggle and tensions around the right to legitimate speech, and in this case, legitimate speech for Africa. Internationalization complicates this reality already experienced by social movements within national frameworks. Dealing in detail with the concrete conditions of transnational protest (a "sociology of the plane ticket") shows where the tensions, alliances and also lines of domination are in the spaces of transnational protest. Focusing on concrete conditions makes it possible to understand how (without being only a reflection of it) certain ideological confrontations are a way of translating, in protest language, realities which correspond to antagonisms of social position on a national or an international scale. This material and symbolic study of the WSF underlines how far the reality of this protest event is from the often portrayed egalitarian image of global civil society. But it also shows how it is possible for newcomers, outsiders, or dominated actors to challenge these unequal relationships through the use of symbols and discourses linked to cultural legitimacy and the possibility of building an "us". Further research will need to address how new hierarchies and new legitimacies acquired in internationalized spaces are used in national contexts.

\section{REFERENCES}

Abdul-Raheem Tajudeen. 2007. “African WSF: It Was a Meeting of NGOs, Not the Masses”, East African Standard, January 28, 2007.

Agrikoliansky, Eric and Isabelle Sommier (ed.). 2005. Radiographie du Mouvement Altermondialiste. Paris: La dispute.

Bayart, Jean-François. 2000. "Africa in the World: A History of Extraversion.” African Affairs 99:217-267.

Bob, Clifford. 2002. "Globalization and the Social Construction of Human Rights Campaigns." Pp. 133-147 in Globalization and Human Rights edited by Alison Brysk. Berkeley: University of California Press. 
Centre de Recherches et d’Informations sur le Développement (CRID). 2007. "Compte-Rendu de la Journée d'évaluation du 17 février 2007.” Paris, unpublished paper.

della Porta, Donatella and Sidney Tarrow Sidney (eds.). 2005. Transnational Protest and Global Activism. Lanham, MD: Rowman \& Littlefield.

Dwyer, Peter and Miles Larmer. 2006. "Four Wheel Drives and Burning Tyres’: Civil Society and Social Movements in Southern Africa." paper delivered at the International Sociology Association World Congress, Durban, July 27.

Gamson, William. 1992. Talking Politics. Cambridge: Cambridge University Press.

Grignon, Claude and Jean-Claude Passeron. 1989. Le Savant et le Populaire. Misérabilisme et Populisme en Sociologie et en Littérature. Paris: Gallimard.

Hlatshwayo, Mondli. 2004. "Le Forum Social Africain: Entre Radicaux et Réformateurs." Pp. 221-226 in Mondialisation des Résistances. L'Etat des Luttes 2004 edited by Samir Amin and Francis Houtart, CETRI. Paris: Syllepse.

Hobsbawm, Eric and Terence Ranger. 1983. The Invention of Tradition. Cambridge: Cambridge University Press.

Igoe, James and Tim Kelsall (eds). 2005. Between a Rock and a Hard Place: African NGOs, Donors and the State. Durham: Carolina Academic Press.

Ngwane, Trevor. 2007. "WSF 2007 in Africa Must Build a Mass Movement Against Capitalism”. Retrieved June 11, 2007 (http://www.cadtm.org/article.php3?id_article=1168)

Organizing Committee of World Social Forum. 2007. "Draft Final Report People’s Struggles, People's Alternatives”, Retrieved on July 2, 2007 (http://www.africansocialforum.org/english/fsm/Kenya2007/report.htm )

Orvis, Steve. 2003. "Kenyan Civil Society: Bridging the Urban-Rural Divide?” Journal of Modern African Studies 41:247-268.

Polletta, Francesca and James Jasper. 2001. “Collective Identity in Social Movements”. Annual Review of Sociology 27:283-305.

Riles, Annelise. 2000. The Network Inside Out. Ann Arbor, MI: The University of Michigan Press.

Rothman, Franklin D. and Pamela Oliver. 2002. "From Local to Global: The Anti-dam Movement in Southern Brazil, 1979-1992”. Pp. 115-132 in Globalization and Resistance Transnational Dimensions of Social Movements edited by J. Smith, F. Johnston. New York: Rowman \& Littlefield.

Sulmont, Rémi. 2004. Le Forum Social Africain: Emergence d'une Mobilisation Transnationale Africaine, Master's Dissertation, Sciences Po Paris.

Tarrow, Sidney. 2005. The New Transnational Activism. Cambridge: Cambridge University Press.

Van der Wekken, Ruby. 2005. “A Picture of the African Social Forum Process”, Network Institute on Global Democracy. Retrieved on October 11, 2007. (http://www.nigd.org/docs/PictureAfricanSocialForumProcess.pdf.)

Wagner, Anne-Catherine. 2004. “Des Syndicalistes Européens. Les Conditions Sociales et Institutionnelles de l'Internationalisation des Militants Syndicaux". Actes de la Recherche en Science Sociale, 155:12-33.

Wing, Susanna D. 2002. "Women Activists in Mali. The Global Discourse on Human Rights". Pp. 172-185 in, Women's Activism and Globalization. Linking Local Struggles and Transnational Politics edited by N.A. Naples, M. Desai.New York : Routledge. 


\section{JOURNAL OF WORLD-SYSTEMS RESEARCH}

Wood, Lesley J. 2005. “Bridging the Chasms: The Case of Peoples’ Global Action”. Pp. 95-117 in Coalitions across Borders. Transnational Protest and the Neoliberal Order edited by Joe Bandy and Jackie Smith. Lanham, MD: Rowman \& Littlefield.

Zuern, Elke. 2006. “La Pauvreté en Débat. Marginalité et Démocratie Constitutionnelle en Afrique du Sud ”. Politique Africaine. 103:27-45. 